ignored. The crude macroscopic indices considered by the scientist of science can be used to demonstrate that, so inexorably does the juggernaut of science roll forward, not even a genius can make a significant contribution to its momentum. But it is not easy to know whether Professor Price is mocking when he says that "Science is, so to speak, a much more regular thing in its behaviour than are people". This assumption, a necessary point of doparture for the science of science as usually construed, is an absurdity which lies at the other extreme from the Cleopatra's Nose school of history. Can it seriously be supposed that if Archimedes, Newton and Einstein had never existed, the present state of science would be no different?

Granted that the individual is insignificant, Professor Price shows how several intriguing "laws" may be set up. The "First Law of Rescarch on Research" is that the "size" of science increases exponentially, whether judged by the number of scientists, scientific journals or scientific papers. It follows that " $87 \frac{1}{2}$ per cent of all the scientists who have ever been are alive now". 'This is an impressive figure indeed and doubtless deserves its place in the Guinness Book of Records, along, perhaps, with a note that a similar figure would probably have been valid in 450 B.c. But what does it show? Professor Price offers this, that "science runs so much faster than people, so much more rapidly than civilization". This would seem to cast the man at the bench in the position of the Red Queen, which may be Professor Price's way of saying that the size of science bears no relation to such wholly immeasurable aspects as its quality or rate of progress at any given time. Alas that the latter aspects, which alone are of significant interest, fall outside the crude scope of the science of science.

No first law is complete without a second, and Professor Price announces the Second Law of Research on Research which states that the distribution of quality among scientific institutions, men or journals follows the approximately inverse square law typical of the Pareto law of distribution of income. "For men as for institutions", Professor Price explains, "the chance of doubling the size of achievement is uniformly about one in four, no matter what the size already achieved." From this follows the premise implicit in the foundation of the argument, that in science (though not, apparently, in art) the individual counts for nothing. "If Beethoven had not existed, other men would have written quite different symphonies; Beethoven's private property is unmistakable. If Planck, however, had not made his particular discovery, somebody else would have to have made it and . . . rather quickly."

As the culmination of his essay, Professor Price produces statistics to show that the size of each country's research effort is proportional to its gross national product. Size is measured by the percentage of papers of each national origin indexed in Physics Abstracts and Chemical Abstracts. (He calls these "National Brownie Points", which is another reason for believing that he may not be entircly serious.) From this analysis it emerges that the Soviet
Union, whose share of the world's GNP is $15 \cdot 6$ per cent, contributed 15.6 per cent of physics papers, while the equivalent figures for the United States are $32 \cdot 8$ and $31 \cdot 6$, respectively. This is a remarkable concurrence, but is it significant? Concurrences in historical and social phenomena have an unfortunate habit of being less meaningful than their counterparts in scientific experiments. George I, II, III and IV all died on a Saturday, but this does not by itself serve to establish the existence of a baneful influence between the Sabbath day and the House of Hanover. The science of science has far to go before it attains respectability. Only Professor Price can know whether his ingenious essay was written to help it on its way or as another obstacle in its path.

\section{Mr R. Brightman}

THE death of Mr R. Brightman at his home in Cheshire last week-end is a particularly sad blow for Nature, for he played an important part in its production for the whole of forty years. He was a chemist by trade, and served for many years in the Dyestuffs Division of ICI Ltd. He had a passion for books and for the scientific literature, which is why no doubt he spent much of his professional energy on the management of the literature. But he also had a great affection for his work for Nature, which began with book reviewing and quickly graduated to other tasks. In the years since the Second World War, when many men of his age would have settled back in their retirement, he found himself writing a great proportion of the leading articles which appeared in Nature. More recently, he took on the job of working through Hansard each week in search of parliamentary news, and he was at the same time hard at work on a volume intended to celebrate the centenary of Nature next year. He would have wished no better monument.

\section{Gloomy Post Office}

THE prospects of the General Post Office for its final year before being established as a public corporation are described in a Government White Paper, just published (HMSO, 1s. 9d.), and presented to Parliament last week by the Postmaster-General. A Bill for the establishment of the corporation will appear later in the year. For the past five years a financial target of 8 per cent was set for the Post Office as a whole, but this has not been achieved. The overall return is expected to be nearer $7 \cdot 6$ per cent, the return from telecommunications, which reached the target, compensating for comparative failures of the postal services. Under the current reorganization these two sections will be managed separately and, because of the different nature of their activities, will airn for different targets. A net return target of 8.5 per cent for telecommunications (after historic depreciation but before interest and supplementary depreciation) has been set, but for the postal service, which is less highly capital. ized, a margin of 2 per cent on total expenditure is being attempted. At present prices, it is unlikely that these targets will be reached. In fact, the postal service expects to make a loss, and, faced with capital 